\title{
Late glacial and Holocene climate variability, southernmost Patagonia.
}

Robert D. McCulloch ${ }^{1,2 *}$, James Blaikie ${ }^{3}$,Barbara Jacob ${ }^{1}$, Claudia A. Mansilla ${ }^{4}$, Flavia Morello ${ }^{5}$, Ricardo De Pol-Holz ${ }^{4}$, Manuel San Román ${ }^{5}$, Eileen Tisdall ${ }^{3}$ Jimena Torres 5 .

${ }^{1}$ Centro de Investigación de Ecosistemas de la Patagonia (CIEP), Coyhaique, Chile.

${ }^{2}$ School of GeoSciences, The University of Edinburgh, Edinburgh, Scotland, UK.

${ }^{3}$ Biological \& Environmental Sciences, University of Stirling, Stirling, Scotland, UK.

${ }^{4}$ Centro de Investigación Gaia Antártica (CIGA), Universidad de Magallanes, Punta Arenas, Chile.

${ }^{5}$ Centro de Estudios del Hombre Austral (CEHA), Instituto de la Patagonia, Universidad de Magallanes, Punta Arenas, Chile.

*Corresponding author: robert.mcculloch@ciep.cl

\section{Abstract}

A Late glacial - Holocene palaeoecological record, constrained by a robust chronology, from a peat bog near Punta Burslem ( $54^{\circ} 54^{\prime} \mathrm{S}, 67^{\circ} 57^{\prime} \mathrm{W}$ ) on Isla Navarino, southernmost Patagonia documents the shifts in intensity and focus of the Southern Westerly Winds (SWWs) at these high latitudes. Such long-term records are required to reconstruct and better understand the likely regional impacts of a poleward shift and intensification of the SWWs predicted under global warming scenarios. Deglaciation at Punta Burslem occurs sometime before c. 17,000 cal a BP, and the post glacial landscape is dominated by cold tolerant pioneer species. Nothofagus woodland is established by c. 12,250 cal a BP, this moisture sensitive vegetation type retreats in the early to mid-Holocene from c. 9700 to 7050 cal a BP reflecting an intense and sustained drier phase associated with a prolonged poleward contraction of the SWWs. After c. $6000 \mathrm{cal}$ a BP there is a regional trend to cooler and wetter climate. However, we identify at least five periods of rapid climate change (RCC) leading to drier conditions at this southern extreme of Patagonia: c. 5350-4750 cal a BP, c.4300-3300 cal a BP, c. 2600-1850 cal a BP, c. 1350-1100 cal a BP and c. 550-350 cal a BP. From a synthesis of our Isla Navarino records and a latitudinal spread $\left(34^{\circ}-64^{\circ} \mathrm{S}\right)$ of multiproxy records it is proposed that these periods of RCC and relatively drier conditions indicate latitudinal shifts in the location and intensity of the SWWs in response to climatic warming leading to reduced precipitation at the southern margins of Patagonia.

Keywords: Palaeogeography; South America; Holocene; Rapid climate change; Southern westerly winds; Vegetation dynamics; Pollen analysis; Pollen preservation. 


\section{Introduction}

Contrasting landmass extents in the mid-high latitudes of the Earth lead to distinctive climates in the northern and southern hemispheres. The dominating feature of the southern mid-high latitudes is the Southern Ocean which allows the prevailing southern westerly winds (SWWs) almost uninterrupted passage to circumnavigate Antarctica. The SWWs are responsible for driving the circulation of the Southern Ocean, the eastwards Antarctic Circumpolar Current (ACC) and the PeruChile Current (PCC) (Lamy et al., 2002; 2015). The SWWs are an important driver of Southern Ocean upwelling and primary productivity (Bakun et al., 2010) and have an important role in the global carbon cycle (Lovenduski and Gruber, 2005; Landschützer et al., 2015). The strength and latitudinal position of the SWWs are predominantly controlled by sea surface temperatures (SSTs) (Lamy et al., 2010). The belt of the strongest velocities of the SWWs along southern South America currently lies between $\sim 50^{\circ}$ and $55^{\circ} \mathrm{S}$ (Lamy et al., 2010) but they seasonally migrate each year in response to the expansion and contraction of Antarctic sea ice and shifts in the Southern Polar Front (Garreaud et al., 2013). The seasonal migration of the SWWs manifests as lower wind velocities over north-central Patagonia but with a wider latitudinal range during the austral winter (June-July-August (JJA)). While southern Patagonia experiences stronger wind speeds and higher precipitation during the austral summer (December-January-February (DJF) (Fig. 1). This pattern has been described as a winter monopole and a summer dipole pattern in the zonal winds and is the principal driver for the distribution of precipitation along the southern Andes (Garreaud et al., 2013). The seasonal strength and position of the SWWs is further controlled by centennial to millennial climate change. The belt of the SWWs may be deflected polewards when there is a strong 'blocking' South Pacific High (SPH) or deflected equatorwards by increasing Antarctic sea-ice (Aceituno et al., 1993). Therefore, during periods of warmer climate the SWWs shift poleward and when there is cooler climate the SWWs shift equatorward (Toggweiler et al., 2006). Modelling of the Patagonian ice sheet suggests the SWWs probably migrated equatorward and increased precipitation between $40^{\circ}$ and $45^{\circ} \mathrm{S}$ during the Last Glacial Maximum (LGM) (Hulton et al., 2002), thus likely reducing the amount of $\mathrm{CO}_{2}$ vented into the atmosphere leading to cooler global temperatures (Anderson et al., 2009). It is also probable that the combination of physical barriers, such as the effect of expanded Antarctic sea ice, slower ventilation of the deep sea, and biological factors led to minimum $\mathrm{CO}_{2}$ concentrations during the LGM (Kohfeld and Chase, 2017).

Inter-annual variability in the strength and position of the SWWs is expressed as the Southern Annular Mode (SAM), with the positive mode characterised as poleward shifts and intensification of 
the SWWs and the negative mode as an equatorward shift and weakening of the SWWs. General circulation models suggest that wind shifts associated with the SAM alter Southern Ocean circulation patterns substantially (Lovenduski and Gruber, 2005). During a positive SAM increased winds drive greater upwelling of carbon from the deep ocean to the surface, diminishing the ability of the ocean to absorb $\mathrm{CO}_{2}$ (Sen Gupta and McNeil., 2012). Although Landschützer et al. (2015) suggest that the development of an asymmetrical distribution of atmospheric pressure systems between the Pacific sector and Atlantic sector of the Southern Ocean leads to a compensatory interaction between temperature and circulation changes leading to a symmetric lowering of $p \mathrm{CO}_{2}$ across the sectors. Present climate change projections suggest that the SAM will become more positive in the future (i.e. stronger and more sustained increases in zonal wind stress) (Christensen et al., 2013). However, modern records are short and there is a growing imperative to reconstruct and better understand the likely regional impacts of a poleward shift and intensification of the SWWs.

Patagonia is ideally situated to reconstruct past migrations of the SWWs due to its southerly maritime location and its palaeoclimatic history is governed by the latitudinal position and strength of the SWWs (Fletcher and Moreno, 2011). It is the most southerly landmass except for Antarctica $\left(\sim 37-56^{\circ} \mathrm{S}\right)$ and is almost surrounded by oceans; the Pacific Ocean to the west, the Atlantic Ocean to the east and the Drake Passage and Southern Ocean to the south (Fig. 1). The present-day vegetation patterns of Patagonia are strongly influenced by the high levels of precipitation delivered by the SWWs. The Andean topography of Patagonia determines the geographical distribution of the precipitation brought by the SWWs. Orographic precipitation is produced as the saturated SWWs reach the western coast and are driven upwards over the Andean Cordillera leading to a hyperhumid region in the west $\left(\sim 8000 \mathrm{~mm} \mathrm{a}^{-1}\right)$ with the moisture decreasing eastwards as the drier air masses descend creating a rain shadow effect ( $\sim 500 \mathrm{~mm} \mathrm{a}^{-1}, 160 \mathrm{~km}$ from the Andean Cordillera) (Schneider et al., 2003). This precipitation gradient is reflected in the ecotones that range from Magellanic Moorland and Evergreen Forest in the west through to Steppe in the east (Tuhkanen, 1989-1990) (Fig. 1). The vegetation response to past climatic changes driven by shifts in the position and / or intensity of the SWWs can be temporally and spatially reconstructed using high resolution and well dated palaeoclimatic and palaeoenvironmental proxy records.

Our understanding of palaeoenvironmental change based on fossil pollen from lakes and mires in Fuego-Patagonia is improving with increasing levels of research in the region during the last decade (Markgraf and Huber, 2010; Ponce et al., 2011; Borromei et al., 2016; Mansilla et al., 2016, 2018; Musotto et al., 2017a, 2017b) (Fig. 1). However, the timing and the nature of the impacts of the 
poleward shifts in the SWWs during the Late glacial and equatorward shifts during the Holocene at higher latitudes is less well understood. Here, we present a new palaeoenvironmental record from southernmost Patagonia from Isla Navarino $\left(\sim 55^{\circ} \mathrm{S}\right)$ south of the Canal Beagle (Fig.1). It is anticipated that the southerly location will enable us, in conjunction with other records of environmental change, to track the poleward influence of the SWWs as they migrated through the Late glacial and Holocene.

\section{Materials and Methods}

2.1 Study area: Isla Navarino

Isla Navarino lies at the southern extremity of Patagonia $\left(\sim 55^{\circ} \mathrm{S}\right)$ and is one of the largest islands in the archipelago south of Tierra del Fuego (Fig.1). The Canal Beagle which separates Isla Navarino from Tierra del Fuego in the north was formed by ice scouring over successive glacial periods from its source in the Cordillera Darwin (Rabassa et al., 2000). The study site, located near Punta (Pta.) Burslem ${ }^{1}$, is an ombrotrophic bog within a closed oval shaped basin ( $\left.230 \times 160 \mathrm{~m}\right)$, probably formed as a kettle hole, located on the northern coastline ( $54^{\circ} 54^{\prime} 05.62^{\prime \prime} \mathrm{S}, 67^{\circ} 57^{\prime} 11.39^{\prime \prime} \mathrm{W}$, altitude $54 \mathrm{~m}$ asl) approximately $25 \mathrm{~km}$ west of Puerto (Pto.) Williams. The current mire is characterised by hummock and hollow complexes. The hollows are occupied by pools of water and Sphagnum moss with lesser amounts of Empetrum rubrum and Gaultheria microphylla on the hummocks. There are scattered trees of Nothofagus antarctica and shrubs of Chilliotrichum spp. around the margins of the peat bog. The landscape surrounding the basin is covered by deciduous Nothofagus pumilio forest with a high abundance of the hemiparasite Misodendrum. In the more open spaces of the forest Berberis microphylla shrubs and Ribes magellanicum herbs are the most dominant species found. The closed nature of the basin suggests the site will be sensitive to changes in precipitation.

\subsection{Sediment coring and laboratory methods}

A $50 \mathrm{~cm}$ long D-section Russian corer $5.5 \mathrm{~cm}$ in diameter (Jowsey, 1966) was used to obtain a continuous core from the site. The Pta. Burslem bog was probed to estimate the deepest point which was cored to $1100 \mathrm{~cm}$ where glacial sediments were retrieved at the base. The stratigraphy of each $50 \mathrm{~cm}$ section was recorded in the field, and cores sealed in layflat tubing and returned to the University of Stirling and stored at a constant $4^{\circ} \mathrm{C}$. The organic content was estimated by Loss-on-

\footnotetext{
${ }^{1}$ The Servicio Hidrográfico y Oceanográfico de la Armada de Chile maps name the point as Punta Burshem. However, the Diccionario Jeográfico de Chile by Luis Risopatrón (1924), gives the name as Punta Burslem which, we believe was so named during the voyage of HMS Beagle in reference to Charles Darwin's marriage to Emma (neé Wedgwood) Darwin and the close association between the Wedgwood family and the Staffordshire town of Burslem.
} 
ignition and $2 \mathrm{~cm}$ thick contiguous samples were dried and then combusted at $550^{\circ} \mathrm{C}$ for 4 hours (LOI $\left.{ }_{550}\right)$ (Fig. 2). Sub-samples $\left(1 \mathrm{~cm}^{3}\right)$ were taken from the core at a resolution of between $16 \mathrm{~cm}$ and $4 \mathrm{~cm}$ and prepared for pollen analysis using standard techniques (Moore et al., 1991). Basal mineral rich samples were treated with Hydrofluoric acid $40 \%$. The identification of pollen grains and spores was supported by a pollen reference collection and supplemented by microphotographs (Heusser, 1971; Villagrán, 1980; Wingenroth and Heusser, 1984; Moore et al., 1991). A minimum total of 300 land pollen (TLP) grains were identified from each sample excluding Cyperaceae, aquatics, spores and algae. The pollen percentage data was divided into local pollen assemblage zones (LPAZ) based on major changes in Land Pollen (>2\% TLP) and constrained by cluster analysis (CONISS) (Grimm, 1987). The pollen results are presented using Tilia software version 2.6.1 (Grimm, 2011) (Fig. 3).

Pollen concentrations were estimated by adding a known quantity of Lycopodium clavatum to each sample (Stockmarr, 1971). The concentration values (No. grains $\mathrm{cm}^{-3}$ ) and sediment accumulation $\left(\mathrm{cm} \mathrm{a}^{-1}\right)$ were used to calculate the pollen and charcoal accumulation rate (influx: No. grains or particles $\mathrm{cm}^{-2} \mathrm{a}^{-1}$ ) (Fig. 4). Charcoal particles between 10-180 $\mu \mathrm{m}$ were also counted alongside the pollen and spores on the microscope slides as an indicator of past fire activity (Whitlock and Larsen, 2001).

The physical condition of fossil pollen within the sediment was also assessed as a further indicator of the environmental conditions in which it was deposited. Pollen grains are well-preserved in anaerobic conditions such as waterlogged mires (Moore et al., 1991). Corroded and degraded pollen grains suggest degrees of chemical deterioration and microbial digestion which indicate a drier aerobic environment and reduced mire surface wetness (MSW). Broken and crumpled pollen suggest mechanical damage, most probably due to abrasion during transportation, such as reworked sediment input to a lake. Each land pollen grain was placed into one of five hierarchical preservation categories; normal, broken, crumpled, corroded and degraded (Cushing, 1967; Lowe, 1982; Berglund and Ralska-Jasiewiczowa, 1986; Tipping, 1987; Mansilla et al., 2018) (Fig. 5).

A cryptotephra layer was identified at $595 \mathrm{~cm}$ during pollen identification and as mineral residue during the $\mathrm{LO}_{550}$ assays (Fig.2). The tephra layer was concentrated by acid digestion of the organic content (Dugmore et al., 1992) and the mineral content assessed using light and polarising microscopy. Volcanic glass shards were identified based on morphology, vesicularity and isotropism under plane-polarised light. The major element geochemical composition of the glass component of the tephra sample was determined by electron microprobe analysis using the SX100 Cameca 
Electron Microprobe at The University of Edinburgh (Hayward, 2012). A minimum of 10 glass shards were analysed to provide a representative geochemical signature (Hunt and Hill, 1993). Tephra identification was carried out through comparisons with geochemical data from previous studies (Mansilla, et al., 2016, 2018) (Table S1).

\section{Results and discussion}

\subsection{Stratigraphy}

The Pta. Burslem stratigraphy comprises bluish-grey clays and silts at the base between 1100 and $1082 \mathrm{~cm}$, with sub-centimetre layers of organic rich sediments between 1096 and $1094 \mathrm{~cm}$, probably deposited during the waning stages of the development of the kettle hole. This is overlain by lacustrine mud which increases from <10\% at $1082 \mathrm{~cm}$ to $\sim 40 \%$ LOI $_{550}$ by $1028 \mathrm{~cm}$. Between 1028 and $910 \mathrm{~cm}$ the organic content of the lacustrine mud plateaus at $\sim 40 \% \mathrm{LOI}_{550}$ and then gradually increases between 910 and $882 \mathrm{~cm}$ suggesting increasing bioproductivity under relatively warmer conditions. The lacustrine phase continues until the transition to peat $\left(>80 \% \mathrm{LOI}_{550}\right)$ at $\sim 882 \mathrm{~cm}$ which then persists to the surface.

\subsection{Chronology}

The chronology of the Pta. Burslem record is constrained by 8 AMS radiocarbon dates from $0.5 \mathrm{~cm}$ thick, $\sim 2 \mathrm{~cm}^{3}$ bulk samples (Table 1). The radiocarbon chronology is supplemented by the presence of the cryptotephra that is geochemically correlated to the eruption of Volcán Hudson (H1) dated to $7241 \pm 23{ }^{14} \mathrm{C}$ a BP (Stern et al., 2016). The Pta Burslem age-depth model was constructed using the $\mathrm{R}$ Bayesian package BACON (Blaauw and Christen, 2011) and the pollen diagrams are constrained using the weighted mean ages (cal a BP).

\subsection{Pollen Stratigraphy}

Eight Local Pollen Assemblage Zones (LPAZ's) are indicated by CONISS based on the percentage pollen data (Fig. 3) and these LPAZs are applied to all the stratigraphic figures to aid comparison.

\subsubsection{LPAZ PB-1 (1095-925 cm; c. 16,800-12,600 cal a BP)}

The basal land pollen assemblage is dominated by well-preserved Empetrum rubrum, Poaceae and Asteraceae Subf. Asteroideae. The basin was occupied by the aquatic Myriophyllum, which peaks towards the middle of the zone and then steadily declines, and the algae Pediastrum is present in large proportions throughout the zone. Although the organic content increases in the first half of the LPAZ pollen influx is very low ( $<1000$ grains $\mathrm{cm}^{-2} \mathrm{a}^{-1}$ ) and continued at this low level until c. $6500 \mathrm{cal}$ a 
BP. The combined stratigraphic evidence suggests the kettle hole was initially colonised by coldtolerant heathland and steppe vegetation and surrounded by a treeless landscape. The site itself was a small lake which as climatic conditions warmed supported shallow rooting Myriophyllum and the algae Pediastrum which favours clear post-glacial water bodies (Komárek and Jankovská, 2001). Myriophyllum steadily increased until c. $14,560 \mathrm{cal}$ a BP and then steadily declined towards the top of the LPAZ at c. 12,630 cal a BP. From the evidence within LPAZ PB-1 it is not clear if the decline in Myriophyllum was a response to cooling during the Antarctic Cold Reversal (ACR) (Gest et al., 2017) and / or a change in water levels. All other proxies continued relatively unchanged during LPAZ PB-1.

\section{Table 1.}

Radiocarbon ages, calibrated age ranges and median ages for the Pta. Burslem record.

\begin{tabular}{cccccc}
\hline Laboratory code & $\begin{array}{c}\text { Depth } \\
(\mathrm{cm})\end{array}$ & Material & ${ }^{14} \mathrm{C}$ yr $(1 \sigma)$ & $\begin{array}{c}\text { Calibrated age range } \\
(95.4 \%) \text { cal yr BP* }\end{array}$ & $\begin{array}{c}\text { Calibrated age range } \\
\text { (wma) at 95\% confidence } \\
\text { (cal yr BP)** }\end{array}$ \\
\hline UCIAMS189856 & 105 & Bulk & $2095 \pm 20$ & $1933-2087$ & $1902-(1995)-2096$ \\
UCIAMS189857 & 359 & Bulk & $3575 \pm 20$ & $3713-3893$ & $3732-(3892)-4192$ \\
UCIAMS189858 & 530 & Bulk & $6200 \pm 20$ & $6968-7161$ & $6902-(7049)-7183$ \\
Tephra H1 & 596 & n/a & $7241 \pm 23^{1}$ & $7949-8152$ & $7935-(8034)-8177$ \\
UCIAMS189859 & 683 & Bulk & $8805 \pm 30$ & $9597-9909$ & $9522-(9721)-9912$ \\
UCIAMS189860 & 813 & Bulk & $10055 \pm 30$ & $11,308-11,707$ & $11,261-(11,460)-11,700$ \\
UCIAMS189861 & 933 & Bulk & $10730 \pm 35$ & $12,562-12,717$ & $12,519-(12,678)-12,792$ \\
UCIAMS189862 & 1045 & Bulk & $12690 \pm 40$ & $14,784-15,222$ & $14,680-(15,033)-15,356$ \\
UCIAMS189863 & 1095 & Bulk & $14070 \pm 70$ & $16,741-17,349$ & $16,267-(16,784)-17,229$ \\
\hline
\end{tabular}

* Calibrated age ranges using Calib 7.10 (Stuiver and Reimer, 1993) and SH13 curve (Hogg et al., 2013).

** Probability interval of calibrated ages and weighted mean ages (wma) using BACON (Blaauw and Christen, 2011).

${ }^{1}$ Age for Volcán Hudson tephra H1 layer from Stern et al. (2016).

\subsection{2. $L P A Z P B-2(925-884 \mathrm{~cm} ;$ c. $12,600-12,180 \mathrm{cal} \mathrm{a} \mathrm{BP)}$}

The Empetrum and Poaceae heath-grassland dominant in the preceding LPAZ begins a punctuated decline and the ground cover Acaena correspondingly increases. Nothofagus dombeyi type pollen (hereafter referred to as Nothofagus) is continuously present and gradually increases to $\sim 10 \%$. Within the lake basin Myriophyllum rapidly peaks to $~ 60 \%$ at the beginning of the LPAZ and then together with Pediastrum virtually disappears at the upper boundary of LPAZ PB-2. This LPAZ reflects a warming climate, coeval with the end of the ACR, and the development of scattered trees in an open grassland. Acaena can thrive on bare ground vacated by the heath and also within more moist areas between trees. The initial rapid expansion of the shallow rooting Myriophyllum likely indicates a lowering of the lake level and expansion of habitat in response to a warmer and drier climate before the site transitioned to a drier peat bog leading to the exclusion of aquatics and algae. In this 
context the earlier decline in Myriophyllum between c. 14,560 and c. 12,630 cal a BP may have been due to a period of relatively cooler climate contemporary with the ACR.

\subsection{3. $L P A Z P B-3 a(884-834 \mathrm{~cm} ; \mathrm{c} .12,180-11,680 \mathrm{cal}$ a $B P)$}

During this sub-LPAZ the Empetrum heath briefly reverses its decline from the preceding zone but is eventually replaced by Poaceae and the establishment of Nothofagus woodland ( 20\% TLP; 'Parque' sensu Burry et al., 2006). However, the pollen proportions swing rapidly between Nothofagus, Empetrum, Poaceae and Subf. Asteroideae. During this LPAZ the degree of pollen preservation also makes a small decline. The evidence presented suggests a continued trend to a drier MSW, and the first decline in Nothofagus may simply be driven by the increased input of the site pollen component as Empetrum was able to spread across the drier surface. The following large expansion of grassland and decline in pollen preservation suggests drier conditions probably constrained the expansion of Nothofagus woodland. Thus, the transition to a more temperate Holocene climate was more of a 'flickering switch' between colder / drier Late glacial and warmer / wetter temperate conditions.

\subsubsection{LPAZ PB-3b (834-775 cm; c. $11,680-10,960$ cal a BP)}

During this sub-LPAZ the expansion of Nothofagus forest continues and this is supported by the presence of the hemiparasite Misodendrum that favours Nothofagus antarctica and Nothofagus pumilio. However, the initial rapid expansion of the woodland cover in LPAZ PB-3b is again interrupted by a brief increase in herbaceous taxa at c. $11,580 \mathrm{cal}$ a BP. This marks the last of the rapid high-magnitude pollen events during the Late glacial - Holocene transition and is followed by a more solid rise in Nothofagus alongside a return of the algae Pediastrum. A relative increase in effective moisture is inferred from the expansion of Nothofagus and the presence of pools of water on the mire surface supporting the return of Pediastrum.

\subsubsection{LPAZ PB-4 (775-668 cm; c. 10,960-9420 cal a BP)}

Nothofagus continues to increase towards the mid-point of this LPAZ, reaching a peak of $\sim 86 \%$ at c. $10,260 \mathrm{cal}$ a BP before declining at the top of the LPAZ. During the first half of the LPAZ Pediastrum makes a resurgence and then disappears from the record. The influx of charcoal particles also peaks at the start of this zone, reaching the maximum level of the entire record $\left(\sim 1620\right.$ particles $\left.\mathrm{cm}^{-}{ }^{2} \mathrm{yr}^{-1}\right)$. Towards the top of the zone the proportion of normally preserved pollen significantly declines. The pollen evidence suggests increasing effective moisture supported the development of closed Nothofagus forest until c. 9700 cal a BP. The large peaks in charcoal influx during this period is slightly counter intuitive as we would expect wetter wood to burn less but the increase in fire 
activity may be seasonal and / or reflect the greater availability of woody fuel. After c. 9700 cal a BP the evidence in LPAZ PB-4 suggests the trend was towards a reduction in MSW and the beginning of a period of prolonged forest contraction.

\subsubsection{LPAZ PB-5 $(668-495 \mathrm{~cm} ;$ c. $9420-6360 \mathrm{cal}$ a $B P)$}

The declining trend in Nothofagus that started in LPAZ PB-4 deepens in LPAZ PB-5 and reaches its nadir at the time of the deposition of the $\mathrm{H} 1$ tephra layer at c. 8000 cal a BP, although the decline is punctuated by brief peaks in Nothofagus. The decline in Nothofagus corresponds to an increase in Poaceae and Subf. Asteroideae. We infer from this pattern a major and sustained shift to drier conditions at Pta. Burslem and this is further supported by the decline in pollen preservation (Normal $54 \%$ ) during this zone. The continued higher charcoal influx values during this period is more consistent with the increased availability of drier fuel. At c. 7050 cal a BP Nothofagus began to restore its dominance, and this also marked the beginning of a fluctuating trend in improved pollen preservation; both suggest gradual rising humidity after this time.

\subsection{7. $L P A Z P B-6(495-359 \mathrm{~cm} ;$ c. $6360-3890 \mathrm{cal}$ a BP)}

Nothofagus continues to steadily increase during LPAZ PB-6 concomitant with the gradual decline and virtual exclusion of all herbaceous taxa. Also, the overall trend to better preserved pollen continued but with significant reversals between c. 5350 and 4750 cal a BP and between c. 4300 and 3950 cal a BP. During LPAZ PB-6 charcoal influx was also substantially reduced. We infer from this evidence that precipitation continued to increase leading to the development of closed Nothofagus forest. However, the climatic trend to increased humidity was interrupted by two periods of rapid climate change and reduced MSW that are not clearly reflected in the percentage pollen data.

\subsection{8. $L P A Z P B-7$ (359-103 cm; c. $3890-1970$ cal a BP)}

This LPAZ is comprehensively dominated by Nothofagus ( 96\%) leading to an almost complete absence of herbaceous taxa, including Poaceae, except for a small and continued increase in Empetrum to 3\% after c. $2660 \mathrm{cal}$ a BP. As the Nothofagus proportions increased, Misodendrum declined and by c. $3000 \mathrm{cal}$ a BP disappears from this LPAZ. At this time land pollen influx values achieve their highest values for the entire record (mean $\sim 6080$ grains $\mathrm{cm}^{-2} \mathrm{yr}^{-1}$ ), largely contributed by Nothofagus. The evidence from this LPAZ reflects a period of sustained increase in effective moisture. A corresponding increase in MSW is also reflected in the increased proportion of normal pollen ( 97\%) and the increased accumulation rate of the peat. At c. $2250 \mathrm{cal}$ a BP there was a decline in pollen preservation suggesting a decrease in MSW, which again is not reflected in the 
percentage pollen assemblages which continues to be dominated by Nothofagus to the upper LPAZ boundary.

\subsection{9. $L P A Z P B-8(103-0 \mathrm{~cm} ;$ c. $1970 \mathrm{cal}$ a $B P$ - present)}

The dominance of Nothofagus in LPAZ PB-7 continues into LPAZ PB-8 with overall proportions remaining $>90 \%$, but with two distinct reductions in tree cover between c. 1850 and c. 1350 and between c. 700 and $350 \mathrm{cal}$ a BP with corresponding increases in Empetrum heath. Misodendrum and trace amounts of herbaceous taxa, e.g. Subf. Asteroideae, Gunnera and Rumex, also return to the record during this LPAZ. The overall trend suggests a shift to a more sustained and / or increase in humidity but punctuated by at least three periods of reduced MSW indicated by brief peaks in pollen influx values and reduced pollen preservation at c. 1850-1710 cal a BP, c. 1250 cal a BP and c. $420 \mathrm{cal}$ a BP. While two of the periods of forest contraction occur broadly at the same time as reduced MSW it would appear that the latter peatland proxy for changes in humidity is more sensitive to short periods of rapid climate change.

\section{Synthesis and climatic inferences}

While there are a growing number of palaeoenvironmental records from the Canal Beagle area and the wider Fuego-Patagonia region (Fig. 1) differences in timespans, methods and approaches often limit close comparison of data. Here, we are able to present a synthesis of the Pta. Burslem record from the western sector of the Canal Beagle with a record from Caleta (Cta.) Eugenia in the eastern sector (McCulloch et al., 2019) (Fig. 6). Both records were produced using the same methods and approaches and our synthesis will provide a more robust reconstruction of the nature and timing of climate change at the southern extreme of Patagonia. Our Isla Navarino records are compared to the diatom inferred precipitation record from Laguna Aculeo ( $33^{\circ} 50^{\prime}$ S) (Jenny et al., 2003); sea surface temperature (ODP1233 and GeoB3313-1, 41 ${ }^{\circ} 00^{\prime}$ S) (Lamy et al., 2010); the pollen record from Mallin Pollux ( $45^{\circ} \mathrm{S}$ ) (Markgraf et al., 2007); moraine building events in the Lago Argentino basin $\left(50^{\circ} \mathrm{S}\right)$ (Kaplan et al., 2016); the dry / warm 'Cipreses Cycles' from Lago Cipreses (51오) (Moreno et al., 2018); magnetic susceptibility (MS) from marine core JPC67 close to the northern outlet glaciers of the Cordillera Darwin Icefield (CDI) $\left(54^{\circ} 31^{\prime}\right.$ S) (Bertrand et al., 2017) and the chronology of Holocene glacier fluctuations of the northern flank of the Cordillera Darwin (Hall et al., 2019). The record of temperature anomalies from the James Ross Island (JRI) ice core $\left(57^{\circ} 41^{\prime} \mathrm{S}\right)$, the closest ice core record to Patagonia, and the duration of marine conditions, i.e. the absence of ice shelves, in the 
Prince Gustav Channel and Larsen A embayment (Mulvaney et al., 2012) are included as a reflection of climate change along the Antarctic peninsula (Figs. 6 and 7).

\subsection{Late glacial environment (c. 17,000-11,700 cal a BP)}

There are few close minimum ages for deglaciation from the Canal Beagle to date. In the eastern sector of the canal a minimum age of 17,760 cal a BP was obtained from Pto. Harberton (Markgraf, 1993). In the western sector of the canal ages of 14,740 and 14,350 cal a BP have been obtained from Valle Holanda and Bahía Pía respectively (Hall et al., 2013). The basal age of c. 17,040 cal a BP from Pta. Burslem is consistent with retreat from a Last Glacial Maximum extent (Rabassa et al., 2000) in response to regional warming as evidenced in the Antarctic ice cores (Jouzel et al., 2007). The slightly older age from Pta. Burslem considering its more proximal location to the CDI is probably more related to its location closer to the wetter end of the west to east precipitation gradient and the promotion of earlier growth and preservation of organic material for radiocarbon dating; a similar phenomenon was observed in the distribution of minimum ages in the Estrecho de Magallanes (McCulloch et al., 2005).

Between c. 17,000 and 12,600 cal a BP the environment along the north coast of Isla Navarino was treeless and dominated by cold tolerant steppe vegetation. An unambiguous response of the terrestrial vegetation at Pta. Burslem and Cta. Eugenia to potential climatic cooling during the ACR is not identified in the pollen records. This is probably because of the dominance and insensitivity of the cold tolerant steppe vegetation to such relatively small-scale temperature changes. There is evidence for changes in the abundance of aquatic flora at Pta. Burslem and slightly reduced pollen preservation at Cta. Eugenia during the ACR which may reflect a reduction in humidity, probably as a result of a continued equatorward focus of the SWWs in response to the relatively cooler climate during the Late glacial. There is a brief period of cooling between c. 14,500 and 13,900 cal a BP suggested by the Deuterium ( $\delta D$ ) analysed from peat mosses from Pto. Harberton (Markgraf and Huber, 2010) which corresponds closely to the magnetic susceptibility peak recorded during the first half of the ACR in the JPC67 core (Fig. 6). There is also tentative evidence for an advance of the Marinelli Glacier during the ACR (Hall et al., 2019). However, the $\sim 1^{\circ} \mathrm{C}$ temperature reduction during the ACR (as suggested by the JRI ice core record) appears to have had minimal impact on the vegetation along the northern coast of Isla Navarino.

The transition between the Late glacial and warmer more temperate Holocene environments took place between c. 12,600 and c. $11,700 \mathrm{cal}$ a BP. The expansion of Nothofagus woodland at Pta. 
Burslem occurred at c. $12,250 \mathrm{cal}$ a BP and slightly lags the warming recorded at JRI but is synchronous with the rise in SSTs at $41^{\circ} \mathrm{S}$ and a small rise in humidity recorded at Cta. Eugenia. The 'flickering-switch' recorded in the Pta. Burslem Nothofagus record was probably a response to the gradual but faltering poleward migration of the SWWs during the last glacial interglacial transition (LGIT). A poleward shift of the SWWs is also suggested by the absence of lake conditions at Laguna Aculeo, which is consistent with a more southerly position of the SPH in tandem with a polewards migration of the SWWs leading to drier conditions in central-south Chile $\left(\sim 30^{\circ}-43^{\circ} \mathrm{S}\right)$ (Schneider et al., 2017) and windier and wetter conditions after c/ 12,500 cal a BP in the vicinity of Gran Campo Nevado ( $\sim 3^{\circ} \mathrm{S}$ ) (Lamy et al., 2010). Relatively drier conditions at Mallin Pollux are suggested by the patchy woodland (Nothofagus $<20 \%$ TLP). This also suggests that between c. 12,600 and c. 11,700 cal a BP the SWWs may have been moving poleward with the northern and eastern sites recording drier conditions and the western and southern sites recording more humid conditions.

\subsection{Early Holocene thermal maximum (Phase i, c. $11,700-10,750$ cal a BP)}

From c. 11,700 cal a BP regional climate continued to warm, and SSTs reached a broad peak by c. 10,750 cal yr BP, a lag of 1000 years after the peak positive temperature anomaly at JRI. As temperatures rose in Fuego-Patagonia closed Nothofagus forest dominated at Pta. Burslem but the same warming and increased SWW speeds probably drove down effective moisture levels at Cta. Eugenia and probably restrained the eastwards expansion of woodland. The earlier age of c. 12,250 cal a BP for forest expansion at Pta. Burslem is likely a reflection of its more western location and sufficient moisture levels enabling the spread of Nothofagus from refugia located to the north (Mansilla et al., 2016; Premoli et al., 2010) into the western sector of the Canal Beagle. The westeast precipitation gradient is also reflected in the difference in pollen preservation recorded at Pta. Burslem and Cta. Eugenia with the former site yielding better preserved pollen grains (Fig. 6). The expansion of Nothofagus takes place against the backdrop of a gradual shift to drier conditions at Isla Navarino, the continued patchy woodland at Mallin Pollux and the absence of lake sediments at Laguna Aculeo. The precise timing of this drier interval (Fig. 6 phase i) is difficult to define but we place it between the decline in pollen preservation at Pta. Burslem and Cta. Eugenia at c. 11,700 cal a BP and the expansion of Nothofagus woodland and the onset of lacustrine conditions at Lago Aculeo after c. 10,750 cal a BP.

The timing of the onset of the early Holocene drier phase appears to be broadly synchronous across the Magellan region. To the north, in the Ultima Esperanza area $\left(\sim 52^{\circ} \mathrm{S}\right)$ a shift to drier conditions leading to lake level lowering and increased fire activity has been identified after c. 11,600 cal a BP 
(Moreno et al., 2012). In the central Magellan region $\left(53^{\circ} \mathrm{S}\right.$ ) a gross reduction in MSW and increase in fire activity has been recorded from c. 11,700 cal a BP (McCulloch and Davies, 2001) and a significant contraction of forest cover and reduced MSW from c. 11,050 cal a BP (Mansilla et al., 2018). In the southern Magellan region $\left(\sim 54^{\circ} \mathrm{S}\right)$ a shift to drier conditions at c. 11,700 cal a BP was also reflected by reduced MSW at Pta. Burslem and Cta. Eugenia evidenced by the reduction in pollen preservation. There was also increased fire activity and reduced forest cover at Pto. Harberton from c. 11,000 cal a BP (Markgraf and Huber, 2010). We argue that during the thermal maximum the SWWs had significantly shifted poleward leading to drier conditions to the north of Fuego-Patagonia (Fig. 7) and increased Drake Passage throughflow of the ACC (Lamy et al., 2015). However, despite this being the period of maximum warmth indicated by the SST and JRI records the ice shelfs along the Antarctic Pensinsula continued to be stable.

\subsection{Early Holocene forest expansion (c. 10,750 - 9700 cal a BP)}

The expansion of Nothofagus woodland at Cta. Eugenia occurred at c. 10,650 cal a BP, some 1600 years later than at Pta. Burslem, which is more in keeping with other records for the establishment and spread of Nothofagus forest (e.g. Borromei, 1995; Heusser, 1998; Borromei et al., 2016). This phase of woodland expansion suggests an interval of increasing humidity and at this time we see a peak in Nothofagus and slightly improved pollen preservation at Pta. Burslem and woodland expansion at Mallin Pollux after c. 10,150 cal a BP. These changes take place as temperature declines at JRI but is still near the thermal maximum in SSTs and the first evidence for break-up of the ice shelf at the northern end of the Prince Gustaf channel, Antarctic Pensinula. This pattern of evidence suggests a more poleward focus of the SWWs between c. 10,750 and 10,000 cal a BP.

\subsection{Holocene dry period (Phase ii, c. 10,100 - 5900 cal a BP).}

During the Holocene dry period the extent of forest contracted at Mallin Pollux, Pta. Burslem and Cta. Eugenia and multiple indicators of MSW indicate a substantial shift to drier conditions (Fig. 6, phase ii). Unfortunately, a marine transgression truncates the climate record from Cta. Eugenia at c. $8650 \mathrm{cal}$ a BP but not before the proportion of normally preserved pollen reached a significant low also indicating a shift to reduced MSW. The increase in normally preserved pollen and forest cover between c. 8650 and $6700 \mathrm{cal}$ a BP was probably due to the wetter marine conditions at the site and so this period is excluded from our synthesis (McCulloch et al., 2019). However, the Mallin Pollux and Pta. Burslem records provide compelling evidence for a sustained and substantial shift to drier conditions. This period broadly encompasses the Extended Warm Dry Anomaly (Moreno et al., 2018). Also, during this period there was the onset of increased ice-shelf instability along the 
Antarctic Peninsula (Mulvaney et al., 2012). Further collapse of the Antarctic Peninsula ice shelves occurred during the Holocene dry period. This was after the early Holocene climate optimum recorded at JRI but at a time when warmer sub-polar waters intruded into the Palmer Deep (Leventer et al., 2002).

In 2019 Laguna Aculeo dried out (NASA, 2019), Holz and Veblen (2013) have identified increased wild fire activity alongside $20^{\text {th }}$ century warming and drying trends in western Patagonia and open marine conditions are returning to the Prince Gustav channels along the Antarctic Peninsula (Mulvaney et al., 2012). This pattern of ocean-atmosphere-land connections is expected to be 'played out' with poleward shifts of the SWWs in response to global warming (Lim et al., 2016). This is potentially further complicated by the linkages between Antarctic ozone loss during spring, the accompanying circulation changes in terms of the SAM, and Southern Hemisphere midlatitude summer surface temperatures (Bandoro et al., 2014). We suggest that the wider environmental impacts of the Holocene 'dry' phase is a close analogue of likely future global warming scenarios for southern South America and should be the focus of urgent research attention.

However, the pattern of evidence from the latitudinal transect suggests the picture is more complex than the SWWs being simply focused more poleward at this time. During the early Holocene warm and dry period, we also see the onset of the Laguna Aculeo lacustrine record which implies an increase, albeit relatively small, in winter precipitation during the seasonal equatorward migration of the SWWs and the SPH. Between c. 10,000 and $8500 \mathrm{cal}$ a BP the water levels in the laguna were at a minimum and frequently dried out, and with precipitation levels estimated at $<200 \mathrm{~mm} \mathrm{a}^{-1}$ (Jenny et al., 2003). During the period of 'extreme' dryness (c. 9700 - 7050 cal a BP) recorded at Isla Navarino and Potrok Aike (c. 9300-7000 cal a BP) (Zolitscka et al., 2013), SSTs temperatures decline, probably due to increased along-shore equatorward winds and coastal upwelling cooling the shelf waters (cf. Schneider et al., 2017). The increase in precipitation at Laguna Aculeo appears to be contrary to the evidence for a substantial poleward shift of the SWWs. This may point to greater seasonal elasticity between a stronger and more poleward focus of the SWWs during the summer and weaker but latitudinally more ranging belt of SWWs during the winter.

During the Holocene dry period we can still see sub-millenial climate variability as there was a brief return to relatively wetter conditions at c. $8300 \mathrm{cal}$ a BP that is closely contemporary with a peak in MS values (c, 8750-8000 cal a BP) recorded in Seno Almirantazgo (Bertrand et al., 2017) (Fig. 6) that may coincide with a glacier advance in the Marinelli fjord at c. 8270 cal a BP (Hall et al., 2019). This 
period is also broadly coeval with a brief increase in Nothofagus at Mallin Pollux and a small stepincrease in precipitation at Laguna Aculeo.

The timing of the end of the early-Holocene dry period appears to vary latitudinally. The period of forest contraction at Pta. Burslem appears to end at c. 7050 cal a BP. Nothofagus at Mallin Pollux rapidly increased around the time of the brief period of wetter conditions at c. $8300 \mathrm{cal}$ a BP and remained dominant thereafter. The lake basin at Potrok Aike began to refill after 7000 cal a BP (Zolitschka et al., 2013) and strengthening of the SWWs after c. 6800 cal a BP is inferred from sedimentary evidence at Lago Cardiel ( $\sim 9^{\circ} \mathrm{S}$ ) (Gilli et al., 2005). However, the pollen preservation evidence from Pta Burslem indicates drier conditions continued until a later step-change at c. 5900 cal a BP which is synchronous with a significant increase in precipitation at Laguna Aculeo. We suggest that the pattern of evidence points towards a more sustained period of drier climate between c. 9700 and 5900 cal a BP but with a period of intense dryness between c. 9700 and 7050 cal a BP.

4.5 Mid- to Late Holocene climate variability (Phases iiii - vi, c. 5900 - 1000 cal a BP) From c. 5900 cal a BP there was a restoration of closed Nothofagus forest at Pta. Burslem from which we infer a rise in humidity. The degree of pollen preservation at Pta. Burslem and Cta. Eugenia also improves suggesting an increase in MSW. The extent of woodland cover at Cta. Eugenia was significantly less (Nothofagus 20\% TLP) and so the expansion of woodland is more gradual and closed woodland is achieved at c. 3000 cal a BP. The diatom inferred precipitation record from Laguna Aculeo suggests a gradual increase in precipitation and the sea surface temperature and the JRI ice core records reflect a gradual decline in temperatures. This pattern is consistent with an equatorward shift of the SWWs in response to climatic cooling leading to increased precipitation along Patagonia and extended reach of the SWW storm tracks to lower latitudes. This trend follows increasing seasonality in insolation (Jenny et al., 2003; Lamy et al., 2010).

The general trend to cooler and wetter conditions is reflected in all the proxies presented here. However, the palaeoenvironmental records from Pta. Burslem and Cta. Eugenia provide evidence for increased climate variability after c. $5900 \mathrm{cal}$ a BP and to the present. From our synthesis we identify at least five periods of rapid climate change (RCC) leading to drier conditions at this southern extreme of Patagonia: phase iii c. 5350-4750 cal a BP, phase iv c.4300-3300 cal a BP, phase v c. 2600$1850 \mathrm{cal}$ a BP and phase vi c. 1350-1100 cal a BP. Not all of these periods are necessarily reflected in changes in the vegetation assemblages of the pollen records but are identified as reductions in MSW 
across the Isla Navarino sites which suggests a degree of resilience (or lags) in the vegetation records. We argue that these periods of RCC and relatively warmer and drier conditions indicate a more poleward focus of the SWWs in response to climatic warming leading to a more sustained dipole SWWs-SPH scenario (cf. Garreaud et al., 2013) (Fig. 7). During periods of warmer climate Isla Navarino probably received more winter precipitation (JJA). However, being located at the margin of the focus of the reduced latitudinal range of the SWWs during summer (DJF) the mire ecosystems were more stressed due to reduced precipitation and increased evaporation. There is also a close positive association between periods of reduced precipitation at Laguna Aculeo and reduced moisture at Pta. Burslem and Cta. Eugenia. The SPH would also have shifted southwards in tandem with the SWWs leading to the increased prevalence of alongshore winds and drier conditions at Laguna Aculeo (cf. Schneider et al., 2017).

The intervening wetter periods (between c. 5900 cal a BP and present) at Pta. Burslem and Cta. Eugenia represent the onset of greater seasonality in the behaviour of the SWWs (Markgraf and Huber, 2010). The wetter intervals suggest a more equatorward shift in the SWWs in response to colder climate conditions leading to a sustained monopole scenario (cf. Garreaud et al., 2013) (Fig. 7) and a northwards shift in the SPH leading to increases in winter precipitation at Laguna Aculeo. We would expect an antiphase behaviour between the precipitation record of Laguna Aculeo and Isla Navarino (Lamy et al., 2015). However, the wetter phases at Laguna Aculeo were closely contemporary with increases in MSW at Isla Navarino, particularly Cta. Eugenia. The oxygen isotope reconstruction of precipitation sources for the past 2000 years from Ariel Peatland on Tierra del Fuego $\left(54^{\circ} \mathrm{S}\right.$ ) (Xia et al., 2018) suggests that periods of more intense westerly air flow coincided with the wetter periods recorded at Isla Navarino. Conversely, periods of increased precipitation at Laguna Aculeo coincided with weaker SWWs at high latitudes which allowed more easterly airflows to penetrate Tierra del Fuego from the South Atlantic.

The wetter and probably cooler periods at Isla Navarino are also contemporary with the large peaks in magnetic susceptibility (MS) from the northern outlet glaciers of the CDI at 5600-3750, 3250-2700 and 2000-1200 cal a BP (Fig. 6). The peaks in MS reflect higher grain-size mode values and are interpreted as periods of vigorous meltwater discharge and glacier retreat (Bertrand et al., 2017). As a general rule, glaciers advance during periods of climatic cooling (Oerlemans, 1993) and so our climatic inferences are at odds with the interpretation of the MS record from Seno Almirantazgo. Here, we argue that the MS peaks are more likely a reflection of increased glacial sediment supply due to increased erosion and meltwater flow into the fjord during glacier advances. This 
interpretation is more in keeping with the peaks in MS reflecting glacier advances during the ACR, at c. $8750-8000$ and moraine building events in the Lago Argentino basin at $6120 \pm 390,4450 \pm 220$, 1450 or $1410 \pm 110$ cal a BP (Kaplan et al., 2016). The sequence of glacier advances reconstructed from the Marinelli fjord also indicates an ice advance at $\leq 6700 \mathrm{cal}$ a BP.

4.6 Little Ice Age to present (c. 1000 cal a BP - present)

After c. 1000 cal a BP there is a significant decline in SSTs and temperature at JRI, a small contraction of forest cover at Pta. Burslem, with small reductions in pollen preservation at both Pta. Burslem and Cta. Eugenia at c. 550-350 cal a BP (Phase vi). This likely reflects cooling during the Little Ice Age (LIA) and is broadly contemporary with moraine building events in the Lago Argentino basin at c. $360 \pm 30$ and $240 \pm 20 \mathrm{cal}$ a BP (Kaplan et al., 2016). LIA cooling likely drove an equatorward shift of the SWWs leading to colder and drier conditions at Pta. Burslem and Cta. Eugenia. The Antarctic ice-shelves began to reform after the last neoglacial advance (c. 1450 cal a BP) and remained stable until the recent collapses during the $20^{\text {th }}$ Century. Again, this is instructive regarding the Holocene 'dry' period analogy for future global warming scenarios as there is a considerable time difference from the loss of the ice-shelves at c. 8000 cal a BP, the increase in precipitation at Laguna Aculeo after c. $3300 \mathrm{cal}$ a BP and inferred equatorward shift of the SWWs and the restoration of the Antarctic Peninsula ice-shelves 1850 years later. Therefore, the recent collapse of the Prince Gustav and Larsen ice-shelves and return of open water is likely to be an enduring feature of the Anthropocene.

\section{Conclusion}

The Pta. Burslem record located along the Canal Beagle ( $\left.\sim 4^{\circ} \mathrm{S}\right)$ strongly reflects a regional climatic pattern and its southerly location provides valuable insights into the latitudinal shifts of the SWWs at the extreme south of Patagonia during the Late glacial and Holocene. Between c.14.5 and c. 13.6k cal a BP the record tentatively suggests a decrease in effective moisture coeval with the timing of the Antarctic Cold Reversal. This was followed by a marked transition from the Late glacial colder environments to warmer and more temperate climatic conditions marking the beginning of the Holocene by c. $11.7 \mathrm{kcal}$ a BP. Higher levels of humidity were registered between c. 10.7 and $9.7 \mathrm{kcal}$ a BP at Pta Burslem and sites located at the same latitude $\left(\sim 54-55^{\circ} \mathrm{S}\right)$ in Tierra del Fuego and Canal Beagle. In contrast, sites located in areas to the north $\left(\sim 53^{\circ} \mathrm{S}\right)$ suggest lower effective moisture during the same interval. The combined evidence suggests stronger westerly winds at the site area due to the poleward migration of SWWs. A sustained period of drier conditions is registered between c. 9.7 and c. $6.0 \mathrm{kcal}$ a BP at the Isla Navarino sites and across Fuego-Patagonia. This strong 
reduction in effective moisture across the region suggests that the influence of the SWWs was weakest during the early to mid-Holocene, perhaps due to their extreme poleward migration leading to instability of the Antarctic Peninsula ice-shelves. A return of higher effective moisture levels at Isla Navarino and across the region is registered after c.5.9 kcal a BP suggesting that the SWWs migrated equatorward in response to cooler climate. However, the Late Holocene is characterised by periods of rapid climate change, probably due to increased seasonality and increasing SST gradients, leading to periods of drier conditions at the southern extreme of Patagonia.

\section{Acknowledgements}

RMcC and BJ are supported by Programa Regional R17A10002 CONICYT, Chile. CAM was supported by PAI/SIA 77180002 CONICYT, Chile. RM, MSR, FM and JT were supported by FONDECYT 1190984, 1140939. CAM, RDP, FM, MSR and JT were supported by NEXER Grant "Carbon Dynamics in the Anthropocene: A perspective from Extreme Environments". JT was supported by PAI/SIA 77170027, CONICYT, Chile. The Scottish Alliance for Geoscience, Environment and Society provided support for the Electron Microprobe analyses of tephra samples. We are grateful to Dr. Chris Hayward for assistance in our use of the Cameca SX100 Electron Microprobe in the School of GeoSciences, The University of Edinburgh; the Servicio de Agrícola y Ganadero (SAG), Coyhaique, for their help with samples; Dr. Steve Roberts for assisting with the analysis of the ERA-INTERIM data; Dr. Mary McCulloch for her assistance with sampling in the field and reading of draft manuscripts and to Professor Mike Bentley, Professor Vera Markgraf and two anonymous reviewers for their constructive comments on an earlier version of this paper. RMcC is indebted to the late Professor Chalmers Clapperton for providing the opportunity to study the Quaternary of Patagonia.

\section{References}

Aceituno, P., Fuenzalida, H., and Rosenblüth, B. 1993. Climate along the Extratropical Coast of South America. In Mooney, H. A., Fuentes, E. R., Kronberg, B. I. (eds.), Earth Systems Responses to Global Change: Contrast between North and South America. Academic Press, New York, U.S.A: 61-69.

Anderson, R.F., Ali, S., Bradtmiller, L.I., Nielsen, S..HH., Fleisher M.Q., Anderson, B.E., Burckle, L.H. 2009. Wind-Driven Upwelling in the Southern Ocean and the Deglacial Rise in Atmospheric $\mathrm{CO}_{2}$. Science, 323: 1443-1448.

Bakun, A., Field, D.B., Redondo-Rodriguez, A., Weeks, SJ. 2010., Greenhouse gas, upwellingfavorable winds, and the future of coastal ocean upwelling ecosystems. Global Change Biology, 16: 1213-1228.

Berglund, B.E., Ralska-Jasiewiczowa, M. 1986. Pollen analysis and pollen diagrams. In: Berglund, B.E. (Ed.), Handbook of Holocene Palaeoecology and Palaeohydrology. Wiley, Chichester, pp. 455-484. 
Bertrand, S., Lange, C.B., Pantoja, S., Hughen, K., Van Tornhout, E., Smith Wellner, J. 2017.

Postglacial fluctuations of Cordillera Darwin glaciers (southernmost Patagonia) reconstructed from Almirantazgo fjord sediments. Quaternary Science Reviews, 177: 265-275.

Blaauw, M., Christen, J.A. 2011. Flexible paleoclimate age-depth models using an autoregressive gamma process. Bayesian Analysis, 6: 457-474.

Bandoro, J., S. Solomon, A. Donohoe, D. W. J. Thompson, Santer, B. 2014. Influences of the Antarctic ozone hole on Southern Hemispheric summer climate change. Journal of Climate, 27: 6245-6264.

Borromei, A.M. 1995. Análisis polínico de una turbera holocénica en el Valle de Andorra, Tierra del Fuego, Argentina. Revista Chilena de Historia Natural, 68: 311-319.

Borromei, A.M., Musotto, L.L., Coronato, A., Ponce, J.F., Pontevedra-Pombal, X. 2016. Postglacial vegetation and climate changes inferred from a peat pollen record in the Río Pipo valley, Southern Tierra del Fuego. In: Martínez, M.A. and Olivera, D.E. (Eds.), Palinología del Meso-Cenozoico de Argentina - Volumen en homenaje a Mirta Elena Quattrocchio. Publicación Electrónica de la Asociación Paleontológica Argentina, 16(2): 168-183.

Burry, L.S., Trivi de Mandri, M., D'Antoni, H.L., 2006. Paleocomunidades vegetales del centro de Tierra del Fuego durante el Holoceno temprano y tardío. Revista del Museo Argentino de Ciencias Naturales, 8: 127-133.

Christensen, J.H., K. Krishna Kumar, E. Aldrian, S.-I. An, I.F.A. Cavalcanti, M. de Castro, W. Dong, P. Goswami, A. Hall, J.K. Kanyanga, A. Kitoh, J. Kossin, N.-C. Lau, J. Renwick, D.B. Stephenson, S.-P. Xie and T. Zhou, 2013. Climate Phenomena and their Relevance for Future Regional Climate Change. In: Climate Change 2013: The Physical Science Basis. Contribution of Working Group I to the Fifth Assessment Report of the Intergovernmental Panel on Climate Change. Stocker, T.F., D. Qin, G.-K. Plattner, M. Tignor, S.K. Allen, J. Boschung, A. Nauels, Y. Xia, V. Bex and P.M. Midgley (eds.). Cambridge University Press, Cambridge, United Kingdom and New York, NY, USA.

Cushing, E.J. 1967. Evidence for differential pollen preservation in late Quaternary sediments in Minnesota. Review of Palaeobotany and Palaeoecology, 4: 87-101.

Dee, D. P., Uppala, S. M., Simmons, A. J., Berrisford, P. , Poli, P., Kobayashi, S., Andrae, U., Balmaseda, M. A., Balsamo, G., Bauer, P., Bechtold, P., Beljaars, A. C., van de Berg, L., Bidlot, J., Bormann, N., Delsol, C., Dragani, R., Fuentes, M., Geer, A. J., Haimberger, L., Healy, S. B., Hersbach, H., Hólm, E. V., Isaksen, L., Kållberg, P., Köhler, M., Matricardi, M., McNally, A. P., Monge-Sanz, B. M., Morcrette, J., Park, B., Peubey, C., de Rosnay, P., Tavolato, C., Thépaut, J. and Vitart, F. 2011. The ERA-Interim reanalysis: configuration and performance of the data assimilation system. Quarterly Journal of the Royal Meteorological Society, 137: 553-597.

Dugmore, A.J., Newton, A.J., Sugden, D.E. 1992. Geochemical stability of fine-grained silicic Holocene tephra in Iceland and Scotland. Journal of Quaternary Science, 7(2): 173-183.

Fletcher, M.S., Moreno, P.I. 2011. Zonally symmetric changes in the strength and position of the Southern Westerlies drove atmospheric $\mathrm{CO}_{2}$ variations over the past 14 k.y. Geology, 39(5): 419-422.

Garreaud, R.D., Lopez, P., Minvielle, M., Rojas, M. 2013. Large-Scale Control on the Patagonian Climate. Journal of Climate, 26(1): 215-230. 
Gest, L., Parrenin, F., Chowdhry Beeman, J., Raynaud, D., Fudge, T.J., Buizert, C., Brook, E.J. 2017. Leads and lags between Antarctic temperature and carbon dioxide during the last deglaciation. Climate of the Past Discussions, doi:10.5194/cp-2017-71.

Grimm, E.C. 1987. CONISS: A Fortran 77 program for stratigraphically constrained cluster analysis by the method of incremental sum of squares. Computers \& Geosciences, 13: 13-35.

Grimm, E.C. 2011. Tilia software v. 2.6.1. Illinois State Museum, Illinois.

Hall, B.L., Porter, C.T., Denton, G.H., Lowell, T.V., Bromley, G.R.M. 2013. Extensive recession of Cordillera Darwin glaciers in southernmost South America during Heinrich Stadial 1. Quaternary Science Reviews, 62: 49 - 55.

Hall, B.L., Lowell, T.V., Bromley, G.R.M., Denton, G.H., Putnam, A.E. 2019. Holocene glacier fluctuations on the northern flank of Cordillera Darwin, southernmost South America. Quaternary Science Reviews, 222: 105904.

Hayward, C. 2012. High spatial resolution electron probe microanalysis of tephras and melt inclusions without beam induced chemical modification. The Holocene, 22: 119-125.

Heusser, C.J. 1971. Pollen and Spores of Chile. The University of Arizona Press, Tucson, Arizona.

Heusser, C.J., 1989. Late Quaternary vegetation and climate of southern Tierra del Fuego.

Quaternary Research, 31: 396-406.

Heusser, C.J. 1998. Deglacial paleoclimate of the American sector of the Southern Ocean: Late Glacial-Holocene records from the latitude of Canal Beagle $\left(55^{\circ} \mathrm{S}\right)$, Argentine Tierra del Fuego. Palaeogeography, Palaeoclimatology, Palaeoecology, 141: 277-301.

Hogg, A.G., Hua, Q., Blackwell, P.G., Niu, M., Buck, C.E., Guilderson, T.P., Heaton, T.J., Palmer, J.G., Reimer, P.J., Reimer, R.W., Turney, C.S.M., Zimmerman, S.R.H., 2013. SHCal13 southern hemisphere calibration, 0-50,000 years cal BP. Radiocarbon, 55: 1889-1903.

Holz, A., Veblen, T.T. 2011., Variability in the Southern Annular Mode determines wildfire activity in Patagonia, Geophysical Research Letters, 38, L14710.

Hulton, N.R.J., Purves, R.S., McCulloch, R.D., Sugden, D.E., Bentley, M.J. 2002. The last glacial maximum and deglaciation of southern South America. Quaternary Science Reviews 21: 233-241.

Hunt, J.B, Hill, P.G. 1993. Tephra geochemistry: A discussion of some persistent analytical problems. The Holocene, 3: 271-278.

Jenny, B., Wilhelm, D., Valero-Garcés, B.L. 2003. The Southern Westerlies in Central Chile: Holocene precipitation estimates based on a water balance model for Laguna Aculeo $\left(33^{\circ} 50^{\prime} \mathrm{S}\right)$. Climate Dynamics, 20: 269-280.

Jouzel, J., Masson-Delmotte, V., Cattani, O., Dreyfus, G., Falourd, S.; Hoffmann, G., Minster, B., Nouet, J., Barnola, J., Chappellaz, J., Fischer, H., Gallet, J. C., Johnsen, S., Leuenberger, M., Loulergue, L., Luethi, D., Oerter, H., Parrenin, F., Raisbeck, G., Raynaud, D., Schilt, A., Schwander, J., Selmo, E., Souchez, R., Spahni, R., Stauffer, B., Steffensen, J.P., Stenni, B., Stocker, T., Tison, J-L., Werner, M., 
Wolff, E.W. (2007). Orbital and millennial Antarctic climate variability over the past 800,000 years. Science, 317(5839): 793-797.

Jowsey, P.C. 1966. An improved peat sampler. New Phytologist, 65: 245-248.

Kaplan, M.R., Schaefer, J.M., Strelin, J.A., Denton, G.H., Anderson, R.F., Vandergoes, M.J., Finkel, R.C., Schwartz, R., Travis, S.G., Garcia, J.L., Martini, M.A., Nielsen, S.H.H., 2016. Patagonian and southern South Atlantic view of Holocene climate. Quaternary Science Reviews, 141: 112-125.

Kohfeld, K.E., Chase, Z., 2017. Temporal evolution of mechanisms controlling ocean carbon uptake during the last glacial cycle. Earth and Planetary Science Letters, 472: 206-215.

Komárek, J., Jankovská, V., 2001. Review of the green algal genus Pediastrum; implications for pollen analytical research. Bibliotheca Psychologica, 108: pp.127.

Lamy, F., Rühlemann, C., Dierk Hebbeln, D., Wefer, G., 2002. High and low latitude climate control on the position of the southern Peru-Chile Current during the Holocene. Paleoceanography 17: http://dx.doi.org/10.1029/2001PA000727

Lamy, F., Kilian, R., Arz, H., Francois, J., Kaiser, J., Prange, M., Steinke, T. 2010. Holocene changes in the position and intensity of the southern westerly wind belt. Nature Geoscience, 3: 695-699.

Lamy, F., Arz, H.W., Kilian, R., Lange, C.B., Lembke-Jene, L., Wengler, M., Kaiser, J., Baeza-Urrea, O., Hall, I.R., Harada, N., Tiedemann, R., 2015. Glacial reduction and millennial scale variations in Drake Passage throughflow. Proceedings of the National Academy of Science USA 112: 13496-13501.

Landschützer, P., Gruber, N., Haumann, F.A., Rödenbeck, C., Bakker, D.C.E., van Heuven, S., Hoppema, M., Metzl, N., Sweeney, C., Takahashi, T., Tilbrook, B., Wanninkhof, R., 2015. The reinvigoration of the Southern Ocean carbon sink. Science, 349: 1221-1224.

Leventer, A., Domack, E.W., Barkoukis, A., McAndrews, B., Murray, J. 2002. Laminations from the Palmer Deep: a diatom-based interpretation. Paleoceanography, 17: 1-15.

Lim, E-P., Hendon, H. H., Arblaster, J.M., Delage, F., Nguyen, H., Min, S-K., Wheeler. M.C. 2016. The impact of the Southern Annular Mode on future changes in Southern Hemisphere rainfall, Geophysical Research Letters, 43: 7160-7167.

Lovenduski, N.S., Gruber, N. 2005. Impact of the Southern Annular Mode on Southern Ocean circulation and biology. Geophysical Research Letters, 32: L11603.

Lowe, J.J. 1982. Three Flandrian pollen profiles from the Teith valley, Scotland. I. Vegetational History. New Phytologist, 90: 355-70.

Mansilla, C.A., McCulloch, R.D., Morello F. 2016. Palaeoenvironmental change in Southern Patagonia during the Late glacial and Holocene: Implications for forest refugia and climate reconstructions. Palaeogeography, Palaeoclimatology, Palaeoecology, 447: 1-11.

Mansilla, C.A., McCulloch, R.D., Morello F. 2018. The vulnerability of the Nothofagus forest-steppe ecotone to climate change: Palaeoecological evidence from Tierra del Fuego $\left(53^{\circ} \mathrm{S}\right)$. Palaegeography, Palaeoclimatology, Palaeoecology, 508: 59-70. 
Markgraf, V. 1993. Palaeoenvironments and paleoclimates in Tierra del Fuego and southernmost Patagonia, South America. Palaeogeography, Palaeoclimatology, Palaeoecology, 102: 53-68.

Markgraf, V., Whitlock, C., Haberle, S. 2007. Vegetation and fire history during the last 18,000 cal yr B.P. in Southern Patagonia: Mallín Pollux, Coyhaique, Province Aisén $\left(45^{\circ} 41^{\prime} 30^{\prime \prime} \mathrm{S}, 71^{\circ} 50^{\prime} 30^{\prime \prime} \mathrm{W}, 640\right.$ m elevation). Palaeogeography, Palaeoclimatology, Palaeoecology, 254: 492-507.

Markgraf, V, Huber UM. 2010. Late and postglacial vegetation and fire history in Southern Patagonia and Tierra del Fuego. Palaeogeography, Palaeoclimatology, Palaeoecology, 297: 351-366.

McCulloch, R.D., Davies, S. 2001. Late-glacial and Holocene palaeoenvironmental change in the central Strait of Magellan, southern Patagonia. Palaeogeography, Palaeoclimatology, Palaeoecology, 173: 143-173.

McCulloch, R., Fogwill, C., Sugden, D.E., Bentley, M., Kubik, P., 2005. Chronology of the last glaciation in central Strait of Magellan and Bahía Inútil, southernmost South America. Geografiska Annaler, Ser. B 87(2): 289-312.

McCulloch, R.D., Mansilla, C.A., Morello, F., De Pol-Holz, R., San Román, M., Tisdall, E., Torres, J. 2019. Late glacial and Holocene landscape change and rapid climate and coastal impacts in the Canal Beagle, southernmost Patagonia. Journal of Quaternary Science, in press.

Moore, P.D., Webb, J.A., Collinson, M.E. 1991. Pollen Analysis. Blackwell Scientific, London.

Moreno, P.I., Villa-Martinez, R., Cardenas, M.L., Sagredo, E.A., 2012. Deglacial changes of the margin of the southern westerly winds revealed by terrestrial records from SW Patagonia $\left(52^{\circ} \mathrm{S}\right)$. Quaternary Science Reviews, 41: 1-21.

Moreno, P.I., Vilanova, I., Villa-Martínez, R., Dunbar, R.B., Mucciarone, D.A., Kaplan, M.R., Garreaud, R.D., Rojas, M., Moy, C.M., De Pol-Holz, R., 2018. Onset and evolution of southern annular mode-like changes at centennial timescale. Scientifc Reports, 8: 3458.

Musotto, L.L., Borromei, A.M., Bianchinotti, M.V., Coronato, A., Menounos, B., Osborn, G., Marr, R. 2017a. Postglacial environments in the southern coast of Lago Fagnano, central Tierra del Fuego, Argentina, based on pollen and fungal microfossils analyses. Review of Palaeobotany and Palynology, 238: 43-54.

Musotto, L.L., Borromei, A.M., Bianchinotti, M.V., Coronato, A. 2017b. Late Quaternary palaeoenvironmental reconstruction of central Tierra del Fuego (Argentina) based on pollen and fungi. Quaternary International, 442: 13-25.

Mulvaney, R., Abram, NJ., Hindmarsh, R.C.A., Arrowsmith, C., Fleet, L., Triest, J., Sime, L.C., Alemany, O., Foord, S. 2012. Recent Antarctic Peninsula warming relative to Holocene climate and ice-shelf history. Nature, 148: 141-144.

NASA 2019. Lake Aculeo Dries Up. NASA Earth Observatory: https://earthobservatory.nasa.gov/images/144836/lake-aculeo-dries-up (Accessed: $7^{\text {th }}$ May, 2019).

Oerlemans, J. 1993. Modelling of Glacier Mass Balance. In: Peltier W.R. (ed) Ice in the Climate System. NATO ASI Series (Series I: Global Environmental Change), vol 12. Springer, Berlin, Heidelberg. 
Pisano, E. 1994. Sectorización fitogeográfica del archipiélago sud patagónico-fueguino: Sintaxonomía y distribución de las unidades de vegetación vascular. Anales del Instituto de la Patagonia, Serie Ciencias Naturales, 21: 5-33.

Ponce, J.F., Borromei, A.M., Rabassa, J.O., Martinez, O. 2011. Late Quaternary palaeoenvironmental change in western Staaten Island $\left(54.5^{\circ} \mathrm{S}, 64^{\circ} \mathrm{W}\right)$, Fuegian Archipelago. Quaternary International, 233(2): 89-100.

Premoli, A., Mathiasen, P., Kitzberger, T., 2010. Southern-most Nothofagus trees enduring ice ages: Genetic evidence and ecological niche retrodiction reveal high latitude $\left(54^{\circ} \mathrm{S}\right)$ glacial refugia. Palaeogeography, Palaeoclimatology, Palaeoecology, 298: 247-256.

Rabassa, J.O., Coronato, A., Bujalesky, G., Salemme, M., Roig, C., Meglioli, A., Heusser, C., Gordillo, S., Roig, F., Borromei, A., Quattrocchio, M. 2000. Quaternary of Tierra del Fuego, southernmost South America: and updated review. Quaternary International, 68-71: 217-240

Risopatrón, L. 1924. Diccionario Jeográfico de Chile. Imprenta Universitaria, Santiago.

Schneider, C., Glaser, M., Kilian, R., Santana, A., Butorovic, N., Casassa, G. 2003. Weather observations across the Southern Andes at 53ㅇ. Physical Geography, 24: 97-119.

Schneider, W., Donoso, D., Garcés-Vargas, J., Escribano, R. 2017. Water-column cooling and sea surface salinity increase in the upwelling region off central-south Chile driven by a poleward displacement of the South Pacific High. Progress in Oceanography, 151: 38-48.

Sen Gupta, A., McNeil, B. 2012. Variability and change in the ocean. In: Henderson-Sellers, A., McGuffie, K. (Eds) The Future of the World's Climate., pp. 141-165. Elsevier, Amsterdam.

Stern, C.R, Moreno, P.I, Henríquez, W.I., Villa-Martínez, R., Sagredo, E., Aravena, J.C., de Pol-Holz, R. 2016. Holocene tephrochronology around Cochrane $\left(\sim 47^{\circ} \mathrm{S}\right)$, southern Chile. Andean Geolology, 43 : 1-19.

Stockmarr, J. 1971. Tablets with spores used in absolute pollen analysis. Pollen et Spores, 13: 615621.

Stuiver, M., Reimer, P.J. 1993. Extended ${ }^{14} \mathrm{C}$ database and revised CALIB radiocarbon calibration program. Radiocarbon, 35: 215-230.

Tipping, R.M. 1987. The origins of corroded pollen grains at 5 early post glacial pollen sites in western Scotland. Review of Palaeobotany and Palynology, 53: 151-161.

Toggweiler, J.R., Russell, J.L., Carson, S.R. 2006. Midlatitude westerlies, atmospheric $\mathrm{CO}_{2}$, and climate change during the ice ages. Paleoceanography and Paleoclimatology, 21: 1-15.

Tuhkanen, S., Kuokka, I., Hyvönen, J., Stenroos, S., Niemela, J. 1989-1990. Tierra del Fuego as a target for biogeographical research in the past and present. Anales del Instituto de la Patagonia, 19: 5-107.

Villagrán, C. 1980. Vegetationsgeschichtliche und pflanzensoziologische Untersuchungen im Vicente Pérez Rosales Nationalpark (Chile). J. Cramer, Vaduz. 
Whitlock, C., Larsen, C. 2001. Charcoal as a fire proxy. In: Last, W.M., Smol, J.P. (Eds.), Tracking Environmental Change Using Lake Sediments Terrestrial, Algal and Siliceous Indicators vol. 3. Kluwer Academic Publishers, Dordrecht.

Wingenroth, M., Heusser, C.J. 1984. Pollen of the High Andean Flora. Quebrada Benjamin Matienzo, Province of Mendoza Argentina. Mendoza: Instituto Argentino de Nivologia y Glaciologia.

Xia, Z., Yu, Z., Loisel, J. 2018. Centennial-scale dynamics of the Southern Hemisphere Westerly Winds across the Drake Passage over the past two millennia. Geology, 46: 855-85.

Zolitschka, B., Anselmetti, F., Ariztegui, D., Corbella, H., Francus, P., Lücke, A., Maidana, N.I., Ohlendorf, C., Schäbitz, F., Wastegård, S. 2013: Environment and climate of the last 51,000 years new insights from the Potrok Aike maar lake Sediment Archive Drilling prOject (PASADO). Quaternary Science Reviews, 71: 1-12. 


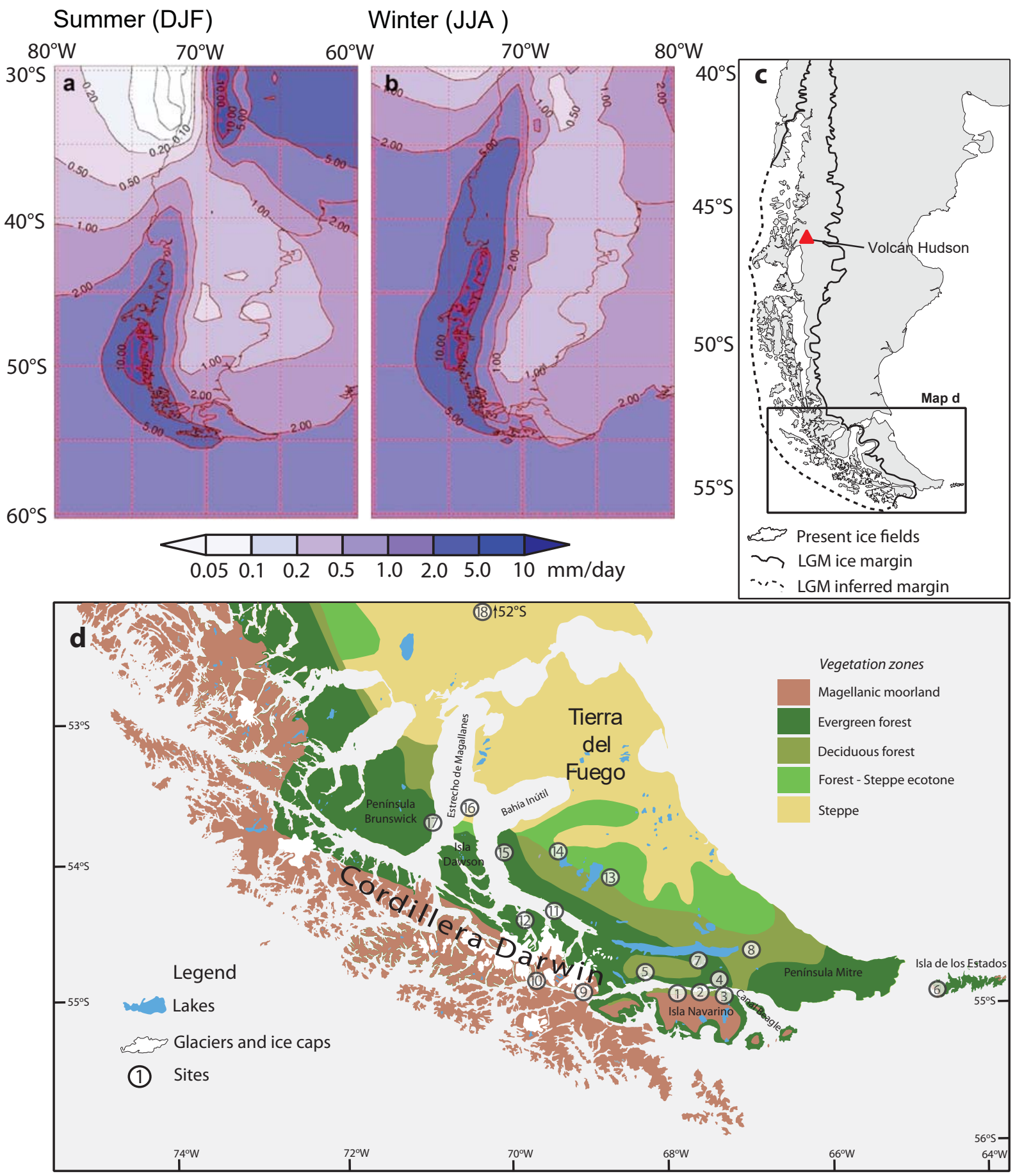

Figure 1. ERA-INTERIM reanalysis data showing mean a) summer and b) winter precipitation rate. c) extent of Patagonian ice sheet during the LGM (McCulloch et al., 2000); d) Fuego Patagonia, the principal vegetation zones are from Tuhkanen et al., (1989-1990) modified with vegetation mapping by Pisano (1994). Sites mentioned in the text are: (1) Pta. Burlsem (this study) (2) Cta. Robalo (Pto. Williams) (Heusser, 1989); (3) Cta. Eugenia (McCulloch et al., 2019); (4) Pto. Harberton (Markgraf and Huber, 2010); (5) Cañadon del Toro (11) Borromei et al., 2016); (6) Cta. Lacroix, Isla de los Estados (Ponce et al., 2011); (7) Terra Australis (Mussoto et al., 2017a); (8) La Correntina (Mussoto et al., 2017b); (9) Valle Holanda and (10) Bahía Pia (Hall et al., 2019); (11) Marine core JPC67 (Bertrand et al., 2017); (12) Glaciar Marinelli (Hall et al., 2019); (13) Aerial peat bog (Xia et al., 2018 (14) Lago Lynch (Mansilla et al., 2018); (15) Pta. Yartou (Mansilla et al., 2016); (16) Est. Esmeralda II and (17) Pto. del Hambre (McCulloch and Davies, 2001); (18) Potrok Aike (Zolitschka et al., 2013). ERA-INTERIM data were downloaded and analysed using the BAS-ECMWF data portal (Dee et al., 2011). 


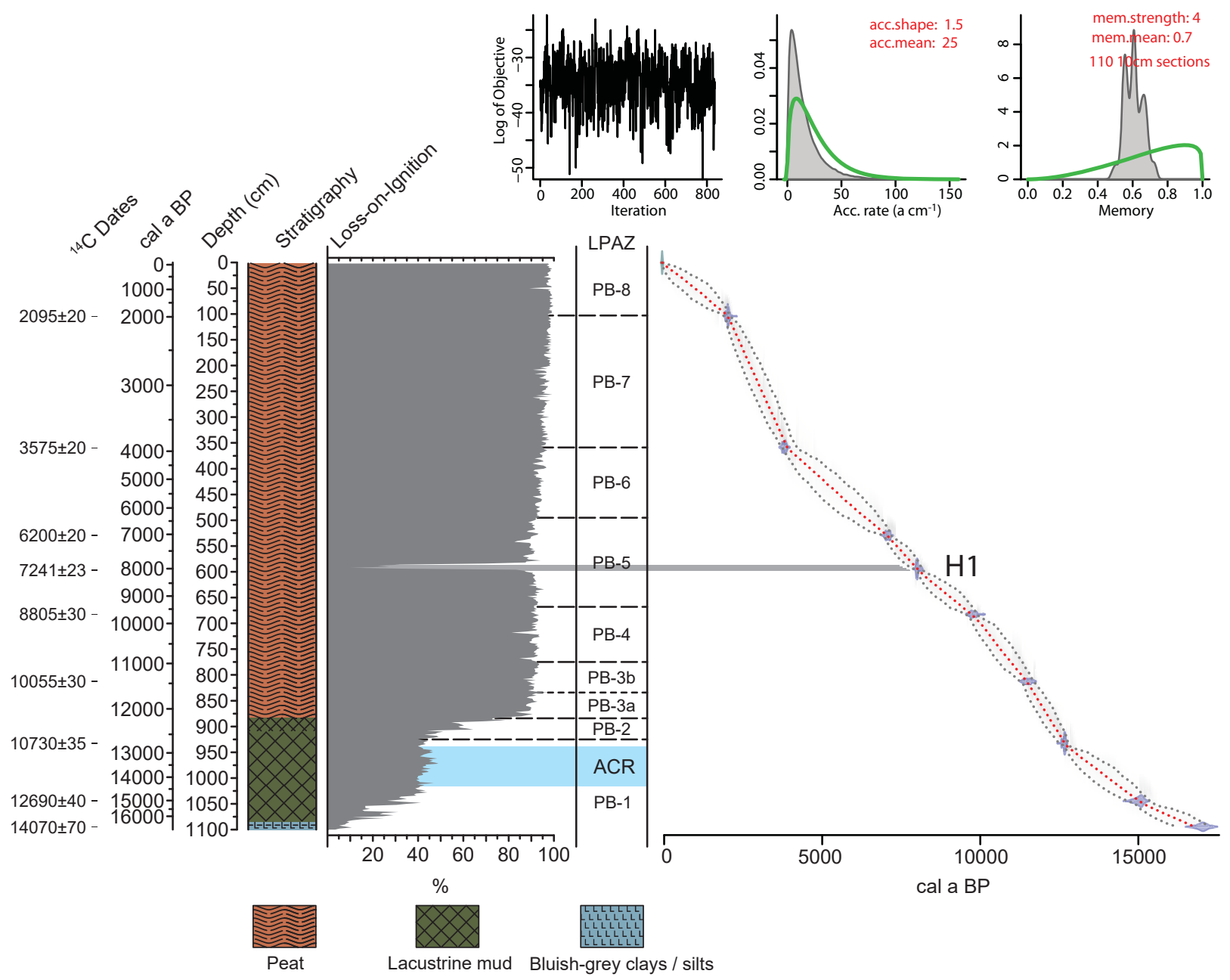

Figure 2. The Pta. Burslem profile: sediment stratigraphy, organic content determined by $\mathrm{LOI}_{550}$, and the LPAZs determined from the percentage pollen diagram (Fig. 3) by CONISS alongside the BACON agedepth model (Blaauw and Christen, 2011). 

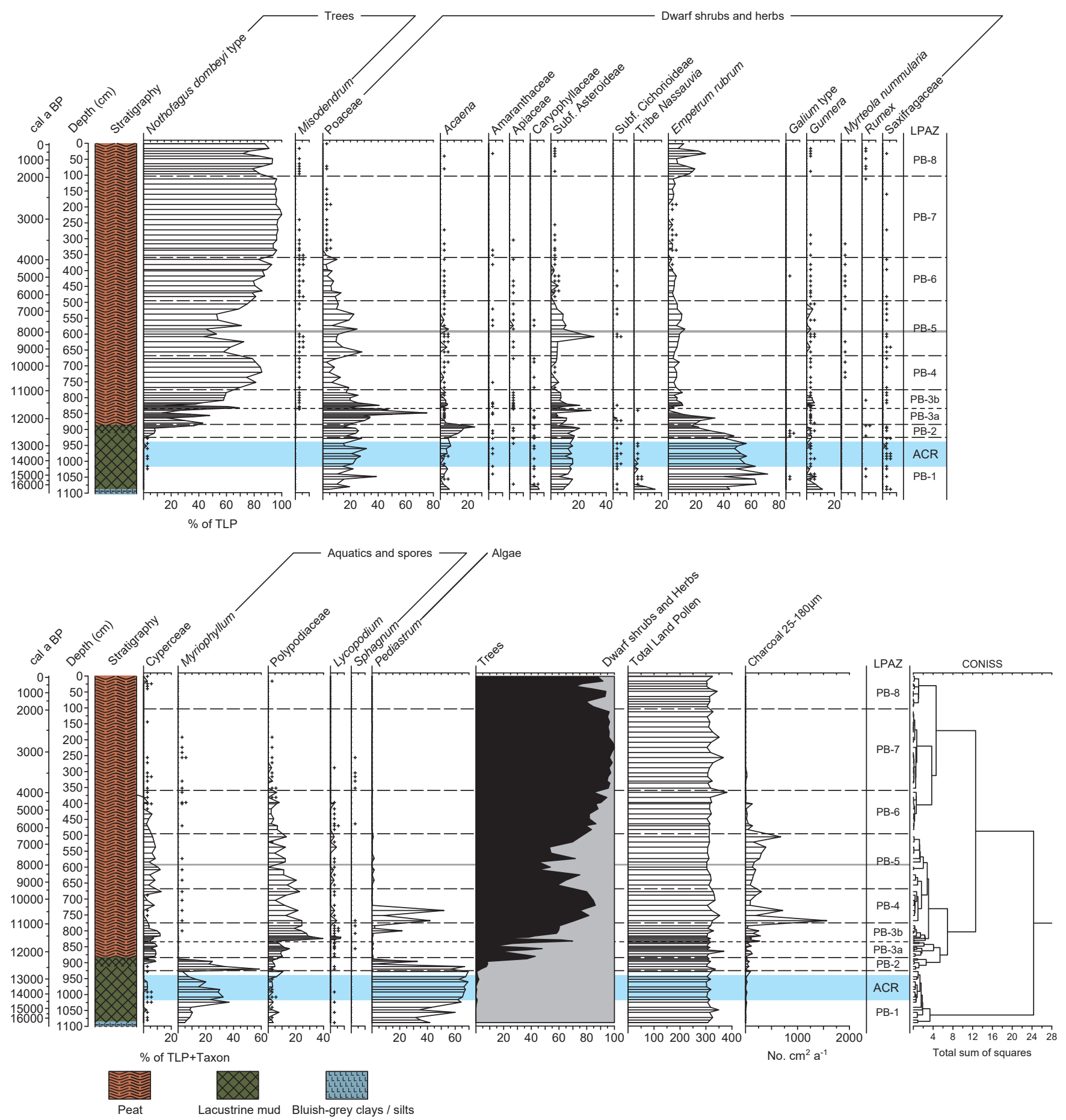

Figure 3. Pta. Burslem summary percentage pollen and spore diagram. Misodendrum is included in the trees group as it is a hemiparasite of Nothofagus trees. The pale blue horizontal band between c. 14,440 and 12,750 cal a BP marks the Antarctic Cold Reversal (Gest et al., 2017). 


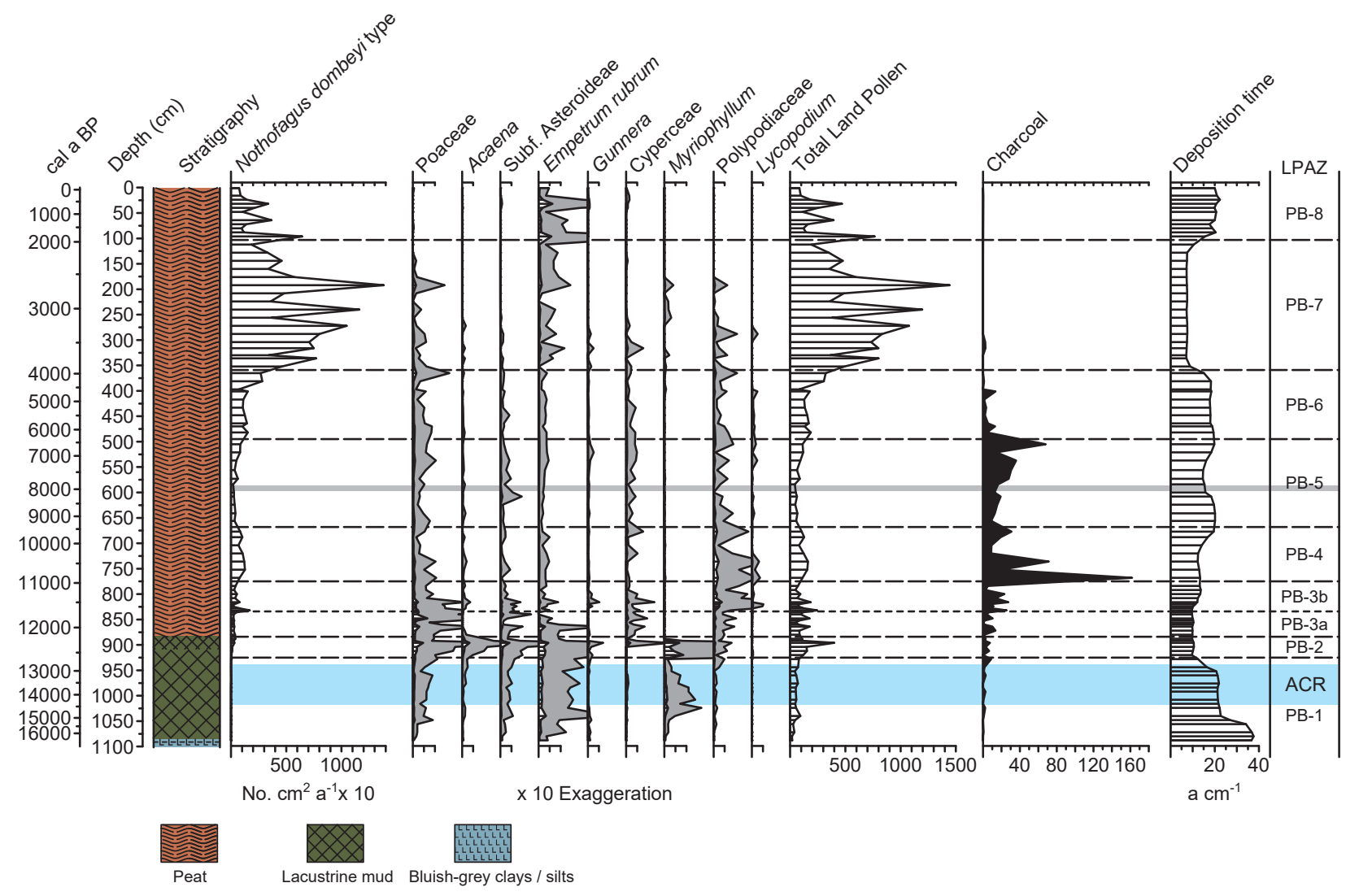

Figure 4. Pta. Burslem pollen accumulation rate (influx) for selected taxa. 


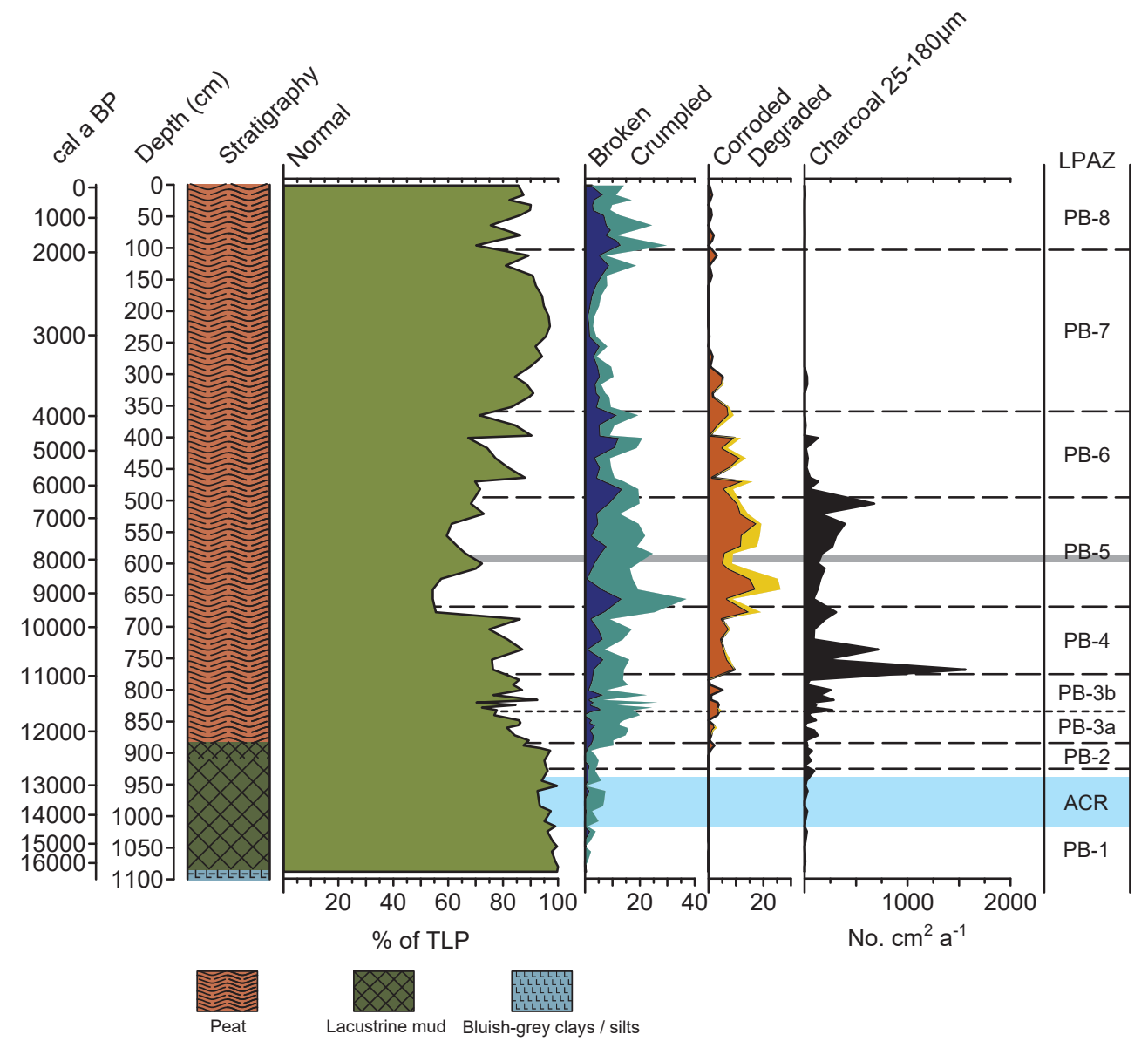

Figure 5. Pta. Burslem percentage pollen preservation diagram and charcoal accumulation rate (influx). 

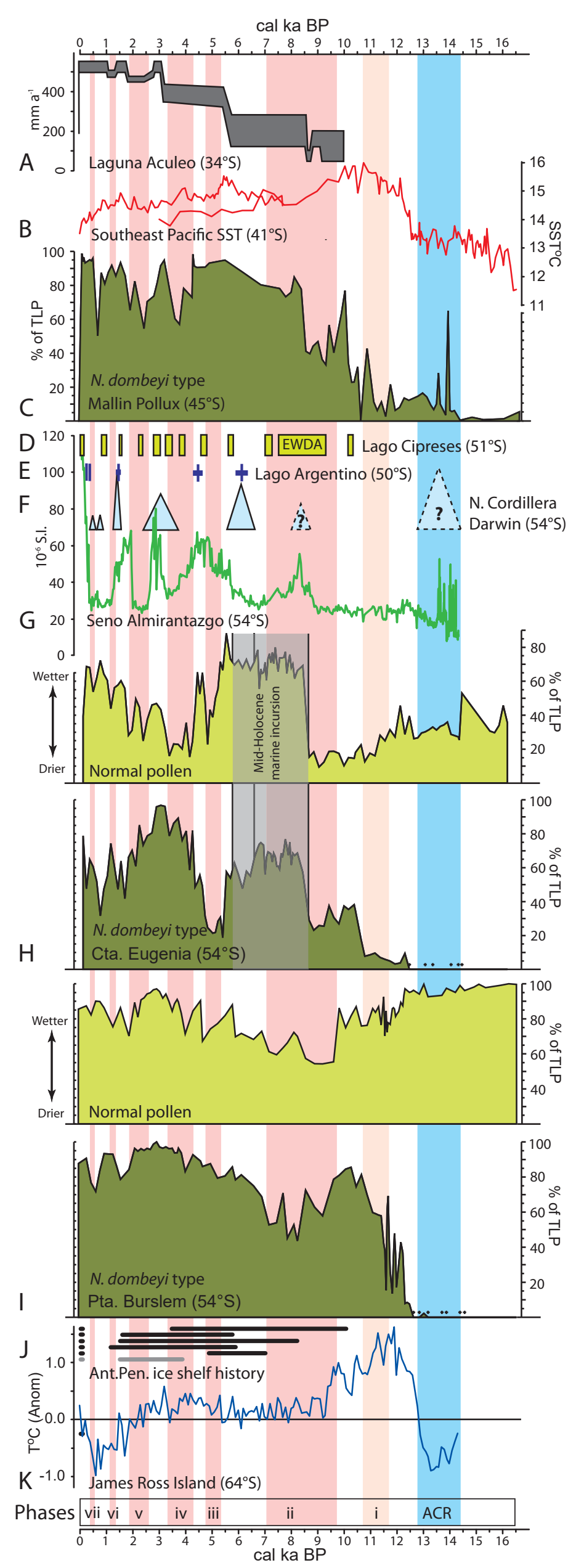

Figure 6. The latitudinal transect of palaeoenvironmental records discussed in the synthesis, from top to bottom: A. Laguna Aculeo ( $34^{\circ} \mathrm{S}$ ) (Jenny et al., 2003); B. Sea surface temperatures (SSTs) from $41^{\circ} \mathrm{S}$, GeoB3313-1 (Lamy et al., 2002) and ODP1233 (Lamy et al., 2015); C. Percentage Nothofagus dombeyi type pollen from Mallin Pollux $\left(45^{\circ} \mathrm{S}\right)$ (Markgraf et al., 2007); D. Lago Cipreses Cycles $\left(51^{\circ} \mathrm{S}\right)$ (Moreno et al., 2018); E. Moraine building events from the Lago Argentino basin (50 $\mathrm{S}$ ) (Kaplan et al., 2016); F. Glacial fluctuations in the Marinelli fjord $\left(54^{\circ} \mathrm{S}\right.$ ) (Hall et al., 2019); $\mathrm{G}$. Volume specific magnetic susceptibility from marine core JPC67 Seno Almirantazgo ( $54^{\circ} \mathrm{S}$ ) (Bertrand et al., 2017); Percentages of Nothofagus dombeyi type pollen and normal preserved pollen from Isla Navarino $\left(55^{\circ} \mathrm{S}\right), \mathrm{H}$. Cta. Eugenia (McCulloch et al., 2019) and I. Pta. Burslem (this study); J. periods of open marine conditions (i.e. loss of ice shelves) in Prince Gustav Channel, Antarctic Peninsula (black; top to bottom are north to south core sites) and Larsen A (grey) ice shelves, which collapsed in AD 1995 and K. Temperature anomaly record from James Ross Island ice core $\left(64^{\circ} \mathrm{S}\right)$ (Mulvaney et al., 2012). The timing of the ACR is indicated by the blue shaded bar from Gest et al. (2017). The pink shaded bars mark the drier periods (phases i to vii) determined primarily by the reductions in mire surface wetness (i.e. reduced percentages of normal pollen) recorded at the Isla Navarino sites. 


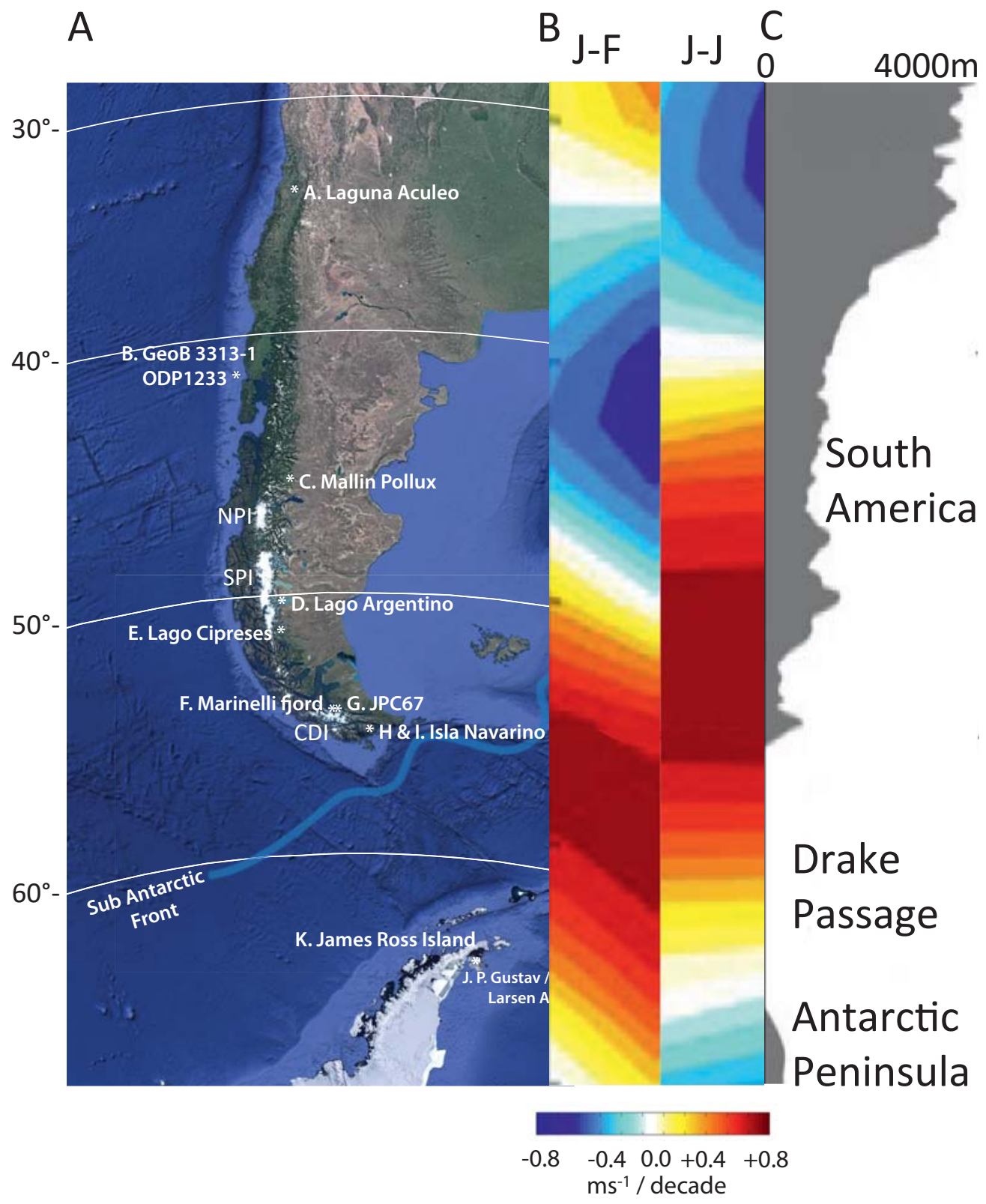

Figure 7: A. Southern South America and the location of the sites (A-K) included in the latitudinal transect (Fig. 6). The latitudinal range of precipitation is reflected in the extent of the greener vegetation pattern along southern Chile (from $\sim 32^{\circ}$ to $56^{\circ} \mathrm{S}$ ). B. The present seasonal (January-February and June-July) latitudinal variation of the leading mode of the 850-hPa zonal wind (U850) between $75^{\circ}$ and $65^{\circ} \mathrm{W}$ and $\mathrm{C}$. the mean Andean topography is shown alongside; from Garreaud et al. (2013). NPI and SPI = North and South Patagonian Icefields respectively, CDI = Cordillera Darwin Icefield. 